\title{
INPUT OF COMMUNAL FORESTS TO SUSTAINABLE DEVELOPMENT OF THE RURAL POPULATION: STUDY CASE OF NORTHERN PORTUGAL AND GALICIA
}

José A. LOPES, Faculty of Agrarian Sciences, University of Lúrio, Niassa, Mozambique, jrlopes1702@ gmail.com Ignacio J. DIAZ-MAROTO, Higher Polytechnic School of Engineering, University of Santiago de Compostela, University Campus s/n, E-27002 Lugo, Spain, ignacio.diaz-maroto@usc.es (corresponding author)

\begin{abstract}
Communal forests occupy one million hectares in the Northern of Portugal and Galicia. Since centuries ago, "Baldios" and "Montes Veciñais en Man Común" (MVMC) played an essential function in the economy of their owner communities. This role was lost all through the last century due to the enormous afforestation and the decrease of agriculture. The restitution of democratic regimes returned the communal forests tenure to the communities. Given the extension and high average area, our paper aims to research its potentialities and limitations of contribution to rural development. Two case studies, one in North Portugal and another one in Galicia, allow identifying the individual and collective traditional uses and the achievements made with revenues linked. Both Galician and Portuguese realities exhibit similarities and complementary benefits, and needing social and economic innovation to make a better use of rural resilience. Communal lands and small-scale business projects could maintain the network of local produce markets with attractive aesthetic values as well as biodiversity conservation. The comparison of the different criteria shows economic aspects are the most valorised by the stakeholders. The management decision of collective forests was the alternative mixed by the communities and the Forestry Services as the best one to complete the main objective of sustainable rural development. As a final conclusion of our work, remarking that the communities owning these forests currently seem to have the conditions to successfully manage their properties if the commoners are able to mobilize and adequate organize the communities.
\end{abstract}

Keywords: Baldios; communal property; management; Montes Veciñais en Man Común; rural resilience

\section{INTRODUCTION}

"Baldios" in Portugal and "Montes Veciñais en Man Común”-MVMC- in Galicia, known as communal forests or communal lands (Balboa, 1995; García, 1998), representing collective forms of tenure and land-use, whose origins date back to a period previous to agriculture and livestock, when man was still nomadic. Such properties persisted throughout the epoch of the pre-Roman "castros", or fortified settlements, they survived the different occupations of the Iberian Peninsula (Roman civilization, numerous Germanic peoples, Arab civilization ...), and even exceeded the formation of different nationalities. Since many thousands of years ago, the communal forests of Northwester Iberian Peninsula made a central and unique role in the rural economy of their owner communities (Baptista et al., 2002). This function was lost during the 20th century due to the massive reforestation with fast-growing species, principally coniferous and different species of eucalyptus, and also of the decline of traditional agriculture. The restoration of democratic governments in Portugal and Spain returned the communal lands to the communities, at present declining, aging, disrupted and disorganized (Sineiro, 1998); as the rural world they belong to, they are at this time facing a number of threats and challenges.

Communal forests occupy approximately 1 million hectares in the "Euroregion" Galicia-North of Portugal, 400,000 hectares in the Northern of Portugal and above of 600,000 ha in Galicia, with high average areas (around 500 hectares in Portugal and more than 200 ha in Galicia). They are owned by in the order of 2900 communities in Galicia and 1000 in North Portugal (DGF information, 1998; MAGRAMA information, 2011). The use of communal lands is predominantly forestry, however several reasons led to a current underutilization of its potential (Sineiro, 1998). Therefore, developing and enhancing integrated models for collective forest management is an essential strategy for the development of rural communities and the revitalization of the rural areas (Marey et al., 2010).

The MVMC and the baldios are now faced with challenges that are general to the rural world, as well as with other challenges arising from the atypical nature of their type of property, from the Germanic law and not the law Romanic (García, 1998; Baptista et al., 2002). The living strength and the basis for their survival lie in the fact that they are an

Copyright (C) 2017 The Authors. Published by Aleksandras Stulginskis University. This is an open-access article distributed under the terms of the Creative Commons Attribution License (CC-BY 4.0), which permits unrestricted use, distribution, and reproduction in any medium, provided the original author and source are credited. 
inseparable reality from the life of the rural populations, strongly marked by a common way of living. According to Saco (1998), "this is a form of collectivism that expresses itself not only in the organization of commons uses but also in the joint usufruct of certain facilities (such as clothes washbasins, hearths, wind- and water-mills) as well as the collective management of water supplies for irrigation, festivities, pathway maintenance and repair, and for performing a number of farming tasks". These communal areas were the support of the traditional agricultural system up until contemporary times and they have played an important and exceptional role in preserving the relationship between landowners, land users, and, of course, the land itself.

Our main objective is to establish the base for a necessary and interesting debate on to what extent the communal forests may feasibly subsist, given their unique form of collective property and the widely democratic nature of their organizational aspects, and surrounded as they are by a different reality that appears to be less and less indifferent to their current existence.

\section{RESEARCH METHODS}

\section{Current situation of communal lands in the Euroregion Galicia-North of Portugal}

The communal lands - MVMC- cover a third of the total forestry area and a quarter of the Galician territory (Figure 1). With the exception of about three percent of the region belonging to public property, all remaining forestry property in Galicia is privately owned (individual or community). The average size of privately forest properties is less than two hectares while the average size of MVMC is more than 200 hectares (Balboa, 1995). Additionally, on the one hand, private properties usually consist of several parcels, as long as mostly communal forests form a single plot. On the other hand, the non-wooded land area is substantially higher in MVMC (Marey et al., 2010). As for its territorial distribution in Galicia, the MVMC are mainly in the South of the area, especially in the mountains of Southern Ourense and Lugo, and also on the whole of the Pontevedra province; however, there are few MVMC in the province of A Coruña and in the Northern of Lugo (MAGRAMA information, 2011; Fernández et al., 2006).

Regarding to Portugal (Figure 1), and according to the estimates of Rodrigues (1987), the baldios are "a living reality covering an area of approximately 400,000 hectares of the national territory". The data submitted by Baptista et al. (2002) at the IV National Conference on Commonlands were of the same order of magnitude, "the total area for the 671 commons on which information could be obtained is 378,574 hectares and show an average area of 500 hectares per baldio" (the authors point, however to the wide diversity of situations that the average data hides). Forest plantations in Portugal, particularly in the North, are also clearly of the small scale property type: more than eighty-five percent of all private properties are less than five hectares, eighty-seven percent of forest land are owned by individuals or different companies, and most of the remaining 15 percent belonging to communal lands, with only from two to three percent state-owned (DGF information, 1998).
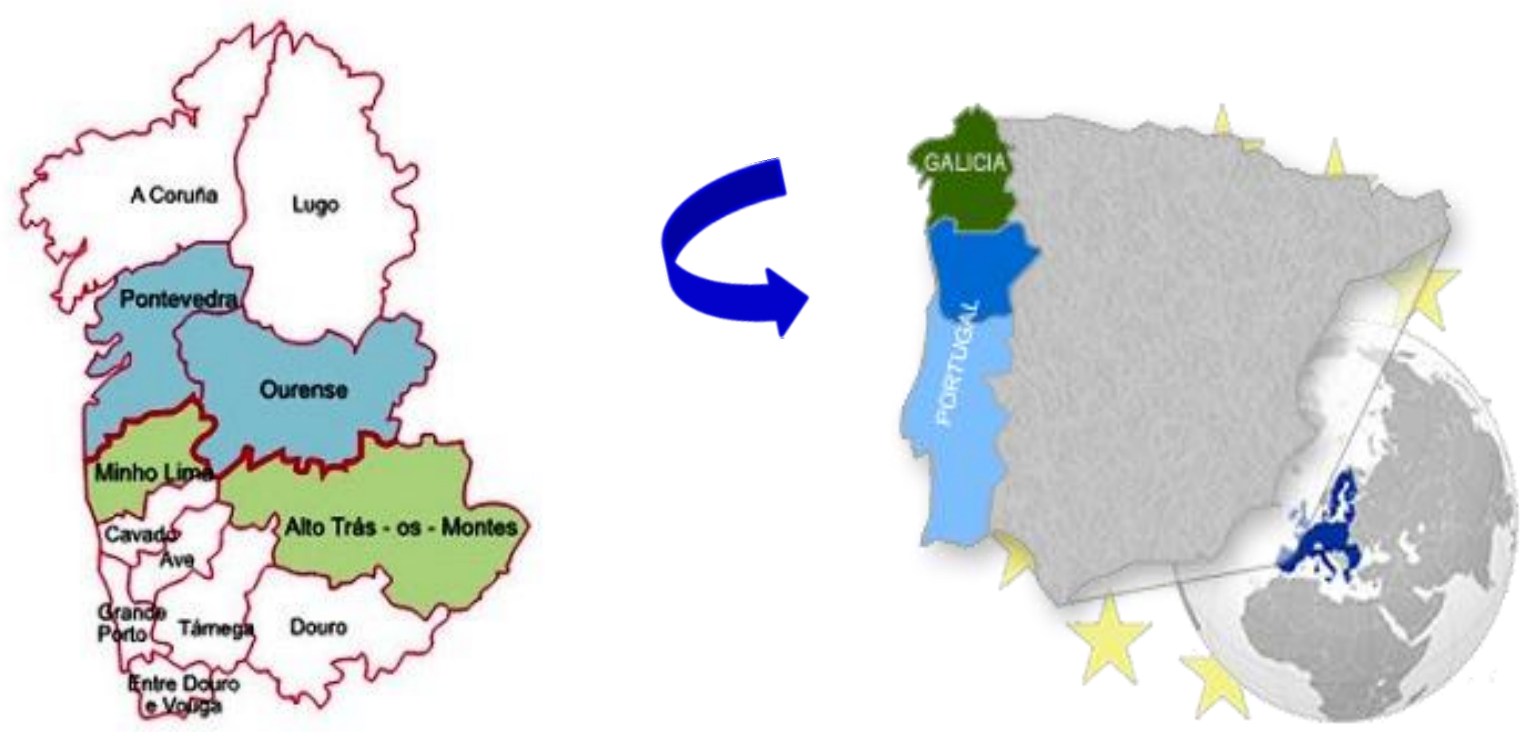

Figure 1. Study area: Galician provinces and districts of Northern Portugal with a greater presence of MVMC and baldios, respectively (Source: elaborated by the authors).

\section{Study area: "núcleo" and "mancomunidade"}

Each of the study case is a grouping of communities owning communal forests. In Portugal there is only one such group "núcleo", established in 2002 by the joint of seven baldios belonging to seven parishes of Amarante (Grande Porto, Serra do Marão) and occupying in total 6817 ha. In Galicia there are 15 groupings “mancomunidades”, the most part located in Pontevedra province. The Galician study case, Community of Ponte Caldelas (Pontevedra), was recognized in 1991 by the combined of seven communal lands, but it has currently 23 communal lands occupying near to 4500 ha. In both cases, their geographic location keeps both communities far from the isolation of the inland regions, however, still 
maintained traditional rural characteristics and typical agricultural activities of collective properties, being more evident in the Portuguese case. In terms of management, in the Northern of Portugal almost the entire area belonging to the núcleo is co-managed with the Forestry Administration, while in Galicia more than $60 \%$ of the area of the community is selfmanaged by the commoners.

\section{RESEARCH RESULTS}

\section{Characterization of communities}

To further characterize the communities, information regarding the populations of the target parishes (North Portugal) and "parroquias" (Galicia) was obtained from the Galician and Portuguese Statistical Institutes (INE, 2004; IGE, 2006); information regarding the uses and exploitation of communal forests was obtained from interviews with community members. Population characteristics are similar in the two areas, with higher percentage of youngsters in North Portugal and higher percentage of elders in Galicia (Table 1). Regarding employment, more population in the Galician studied parroquias is working in services sector, while in Portugal more population in the objective parishes is employed in the industrial and construction sector (Table 1).

The number of commoners involved in the Galician case depends on legal criteria of the MVMC, which distinguishes between residents and commoners. Law 13/1989 of the Communal Lands (DOG information, 1989) establishes that in each resident family (or economic unity) only one member can be a commoner. According to the Portuguese law all residents also are commoners. Therefore and in accordance with said laws, in the Ponte Caldelas community there are 1150 commoners and using the same criteria for the Portuguese case, there are 1400 commoners in the Amarante núcleo. Also highlight that none of the communal forests in the Portuguese núcleo has land-use planning and in the Galician case, only one third of the 23 communities have such planning.

Table 1. Population characteristics and employment in the parishes (North Portugal) and Galician parroquias [Source: Galician and Portuguese Statistical Institutes INE (2004) and IGE (2006)]

\begin{tabular}{lll}
\hline & North Portugal & Galicia \\
\hline Age distribution $(\%)$ & & \\
$<14$ years & 19.4 & 10.9 \\
$15-64$ years & 62.4 & 63.9 \\
$\geq 65$ years & 18.3 & 25.2 \\
Employment $(\%)$ & & \\
Agriculture and fisheries & 13.3 & 5.3 \\
Industrial and construction sector & 49.4 & 34.6 \\
Services sector & 37.3 & 60.1 \\
\hline Total population & 4185 & 5921 \\
\hline
\end{tabular}

\section{CONCLUSIONS AND DISCUSSION}

The results show that in both the Portuguese and the Galician cases, the individual use of communal lands endures. Its importance is reduced in numerical and economic terms, and they do not assure the income of families, although uses such as the gathering of wood and bushes are still widely practiced by community members (Frederik, 2006). Despite this scenario, the accomplishments made with revenues from the communal forests are significant. These revenues often allowed the communal lands to replace the role of central or local Administration in the building of several infrastructures in their villages. Regarding the collective use of these lands, forestry dominates over other uses. In both studied cases, uncontrolled wildfires recently destroyed large forest areas, the risk and magnitude of the fires being enhanced by the existence of monocultures of pine in North Portugal and eucalyptus in Galicia. Grazing, as a collective activity disappeared in the Portuguese núcleo; in Ponte Caldelas mancomunidade there is still an important activity in some community. One of the most important income sources is currently the installation of Aeolian parks. However, even in this apparently successful use, there a noticeable lack of knowledge and negotiation power by part of the communities owning these lands. There are very few tourism initiatives, but these forests are used for various recreational and leisure activities.

The low participation level in the life of the communal forests is partly due to the co-management model; disinterest being a giving-up reaction to the often no agreeable decisions or to the long waiting for answers. The Administration theoretically decides on basis of the general society interests, but often those interests are not discussed with local stakeholders (Ravnborg and Westermann, 2002). The Portuguese Administration does not have land-use planning and in the Galician case, only one third of the 23 communities have such plans. Inside the communities leaders sometimes react against the giving-up, and if there is any support to the communal lands it are due to this leadership. Still regarding participation, it is notorious the lower participation in the Portuguese case, which may be related to the legal administrative body in both countries. In Portugal the parishes are administrative organs at the community level, sometimes replacing - either by imposing themselves or because the communities are inactive- the commoners in the management of their communal forests. In Galicia the parroquias have no administrative functions, creating an administrative void occupied by the communities.

Employment data of the both areas shows that agriculture is no longer the main income source of these populations (Table 1). The resulting altered relation between people inhabiting the rural areas and the land is followed by a change in people's habits and the adoption of more urban values and practices. Communal lands are now places for diverse 
entrepreneurial initiatives, in the area of telecommunications, energy or tourism projects. Does this disconnection between agrarian activities and the new uses of communal forests condition a new type of community? Is cohesion of the current communities different from the previously existing cohesion in the "old" communities?

The old communities were based on a subsistence economy; their productions were destined to their own consumption, not to the market. Their law was one of traditional uses and customs. On the one hand, due to the relationships among people and between people and land, these communities were more homogeneous than current communities. Personal relations dominated over impersonal, mundane relations, and family and neighbourhood bonds cemented their cohesion (Balboa, 1995). On the other hand, they used "to do without" instruction, experimentation or speculation. Cooperation, materialized in communitarian actions (e.g. grazing, use of common equipment such as the communitarian oven) was dictated by necessity. In spite of the essentiality of cooperation, did these old communities have a self-conscience of their potential and strength (Feeny et al., 1990)?

Cohesion is one of the most important factors controlling the strength of a community, and strong communities are more capable to assume rights and responsibility towards their lands. Are there any current activities in the communal lands contributing to the cohesion of the communities? Is cohesion dependent on the revenue of these activities or on the existence of financial support? Or may we assume that some activities strengthen the identity of the communities and thus their cohesion, independently of the incomes? The continuation of cohesion in the communities depends on the individual uses, collective exploitation, the existence of revenues, and on the interest of the community members to exert their property rights, i.e. the individual, but also collective use of their communal forests. In both the baldios (Rodrigues, 1987) and MVMC (Fernández et al., 2006), open access does not exist. Resources belong to the communities and their multiple uses may be forbidden to outsiders. If they exert their right to the land, communities commit with their duties and assume themselves as social entities, cementing cohesion. Otherwise, they weaken their organization, as shown, for instance, by the low level of participation in meetings. Organization is reinforced if they participate -individually or encouraged by external agents- with their experience and knowledge in the management and decision taking of development projects adapted to local conditions. Communal lands persist as a wealth source, maintaining the culture of diverse and multifunctional uses. Their development model is specific, valorising resources with no market value. The opportunities for reworking of rural space expansion based upon low impact development are well shown by Halfacree (2007).

The communities and this particular form of property -incongruous in times of economic liberalism, and tempting for the city councils and for new forms of entrepreneurialism- will survive better if they become an active part of local development projects, and they can do that if they enhance the strong points associated to their functioning (Edwards and Steins, 1999). Moreover, these communities have a great potential regarding human and natural resources (Feeny et al., 1990). More than half of the commoners are women. While in a number of other environments the role of women is strictly limited to the private and domestic spheres, and hence their frequent invisibility, the inland rural communities usually cannot do without the women's productive input. Besides, migration towards the urban centres, national or foreign, involves men in particular, while women stay home looking after the "rearguard". Despite the sometimes dominant role of women in the farm, as when it comes to household chores, and although the impact that social and economic changes have on women and men and on gender-specific organizational aspects (Edwards and Steins, 1999) the role of women as producers is not always appropriately acknowledged.

\section{REFERENCES}

1. Balboa, X. 1995. Os Montes Veciñais en Man Común e o Sistema Agrario na Idade Contemporánea: da Integración á Marxinación [The Neighborhood Forests in Common Man and the Agrarian System in the Contemporary Age: from Integration to Margination]. Proceedings of the Congreso de Montes Veciñais, pp. 39-53, Xunta de Galicia y Asociación Forestal de Galicia, Santiago de Compostela. [In Spanish]

2. Baptista, F., Lourenço, F., Santos, R.T., Simões. S. 2002. Os Baldios. Um Panorama da Região Norte [The Baldios. A Northern Region Overview]. Proceedings of the IV Conferência Nacional dos Baldios, pp. 35-48, Federação Nacional dos Baldios, Vila Real. [In Spanish]

3. Diario Oficial de Galicia (DOG) 1989. Lei 13/1989, do 10 de outubro, de Montes Veciñais en Man Común. [Law 13/1989 of 10 October of the Communal Lands]. Diario Oficial de Galicia número 202, Consellaría de Medio Rural, Xunta de Galicia, Santiago de Compostela. http://mediorural.xunta.gal/fileadmin/arquivos/normas/lei_13_1989.html [In Spanish]

4. Direcção Geral das Florestas (DGF) 1998. Plano de Desenvolvimento Sustentável da Floresta Portuguesa [Sustainable Development Plan for the Portuguese Forest]. Direcção-Geral das Florestas, Lisboa.

5. Edwards, V., Steins, N.A. 1999. A framework for analysing contextual factors in common pool resource research. Journal of Environmental Policy \& Planning, No. 1, pp. 205-221. https://doi.org/10.1080/714038536

6. Feeny, D., Berkes, F., McCay, B.J., Acheson, J.M. 1990. The tragedy of the commons: twenty-two years later. Human Ecology, Vol. 18, pp. 1-19. https://doi.org/10.1007/BF00889070

7. Fernández, X., López, E., Jordán, M., Besteiro, B., Viso, P., Balboa, X., Fernández, L., Soto, D. 2006. Os Montes Veciñais en Man Común: O Patrimonio Silente. Natureza, Economía, Identidade e Democracia na Galicia Rural [The Montes Veciñais en Man Común: The Silent Patrimonio. Nature, Economy, Identity and Democracy in the Rural Galicia], Edicións Xerais, Vigo.

8. Frederik, J. 2006. Rural youths' images of the rural. Journal of Rural Studies, Vol. 22, pp. 409-421. https://doi.org/10.1016/j.jrurstud.2006.01.005

9. García, J. 1998. O monte veciñal en man común: outro modo de posuír [The monte veciñal on common hand: another way to possess]. Cooperativismo e Economía Social, Vol. 18, pp. 63-73. 
10. Halfacree, K. 2007. Trial by space for a 'radical rural': Introducing alternative localities, representations and lives. Journal of Rural Studies, Vol. 23, pp. 125-141. https://doi.org/10.1016/j.jrurstud.2006.10.002

11. Instituto Galego de Estatística (IGE) 2006. Enquisa de Condicións de Vida [Survey of Living Conditions]. Available at http://www.ige.eu/ga/sociais/benestar/cvida/ (Accessed on 13/11/2017)

12. Instituto Nacional de Estadística (INE) 2004. Estatísticas Territoriais [Territorial Statistics]. Available at http://www.ine.pt/portal/page/portal/PORTAL_INE (Accessed on 13/11/2017)

13. Ministerio de Agricultura, Alimentación y Medio Ambiente (MAGRAMA) 2011. Cuarto Inventario Forestal Nacional [Fourth National Forest Inventory], Galicia, Madrid.

14. Marey-Pérez, M.F., Gómez-Vázquez I., Díaz-Varela, E. 2010. Different approaches to the social vision of communal land management: the case of Galicia (Spain). Spanish Journal of Agricultural Research, Vol. 8, pp. 848-863. https://doi.org/10.5424/sjar/2010083-1287

15. Ravnborg, H.M., Westermann, O. 2002. Understanding interdependencies: stakeholder identification and negotiation as a precondition to collective natural resource management. Agricultural Systems, Vol. 73, pp. 41-56. https://doi.org/10.1016/S0308$521 \mathrm{X}(01) 00099-3$

16. Rodrigues, M. 1987. Os Baldios, Editorial Caminho, Lisboa.

17. Saco, V. 1998. As comunidades de montes e a organización das parroquias: un estudio de caso [The communities of forests and the organization of the parishes: a case study]. Cooperativismo e Economia Social, Vol. 18, pp. 47-62.

18. Sineiro F. 1998. Montes veciñais en man común: as súas funcións no sistema agrario tradicional, conflictos xurdidos coa súa propiedade e posibilidades ofertadas pola lei 13/1989 [Montes veciñais on common man: their functions in the traditional agrarian system, conflicts arisen with their property and possibilities offered by law 13/1989]. Cooperativismo e Economía Social, Vol. 18, pp. 35-45. 